ISSN 1991- 8690

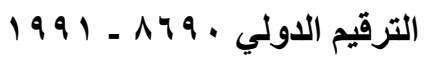

website : http:// jsci.utq.edu.iq

Email: utjsci@utq.edu.iq

\title{
The Effect of $\gamma$-ray doses on Phagocyte Functional activity of Granulocytes by mean of Chemiluminescence
}

\author{
Ferial Y. Nazal \\ Hussain A. Hussain* \\ Ali H. M. Al-Hashimi** \\ ferial.nazal@yahoo.com \\ hkhursan@yahoo.com \\ dr.ali47@yahoo.com
University of Thi-Qar - College of Medicine - Dept. of Medical Physics
*University of Basra - College of Science - Dept. of Physics. \\ **University of Basra - College of Medicine.
}

\begin{abstract}
$\underline{\text { Abstract }}$
White blood cells are the fundamental viable defense barrier in the body immune system against foreign bodies such as bacteria parasites viruses. All types of leukocytes have the ability to produce reactive oxygen species such as singlet oxygen ${ }^{1} \mathrm{O}_{2}$, super oxide $\mathrm{O}_{2}$, hydroxyl radical $\mathrm{OH}$ and hydrogen peroxide $\mathrm{H}_{2} \mathrm{O}_{2}$ in the process of Phagocytosis and respiratory burst. When leukocytes exhibit respiratory burst, this process will cause light emitting and this will called Chemiluminescence (CL). The emitted light is very weak and requires some materials to increase the light intensity for detection. Chemiluminescence (CL) is a new technique used in this study to find out the effect of gamma rays on the white blood cells, as used Luminol to increase the detection of light intensity. Gamma ray will produce free radicals from the excitation reactions with the materials. The somatic damage of radiation may be tolerated if whole body exposure was in a low rate and extended over a long period of time. Sensitivity, resistance and reactive activity of White blood cells (WBCs) will react differently to gamma radiation according to their characteristics and body repair mechanisms. Gamma ray doses have been studies to see it is effect on control and test blood cell samples. This was done under same PH. This will make changing in the CL values.
\end{abstract}

Keywords: Granulocytes, Phagocytosis, Chemiluminescence, Luminol.

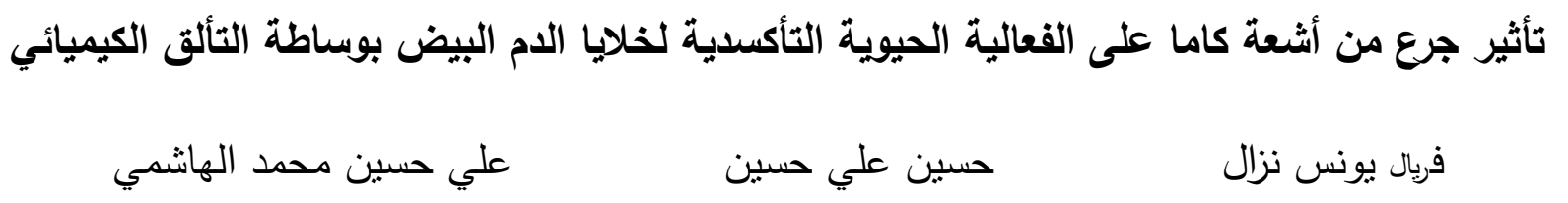

الخلاصـة

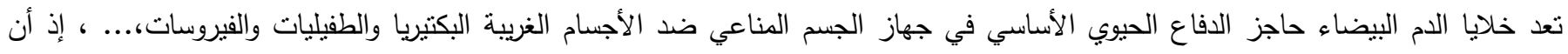

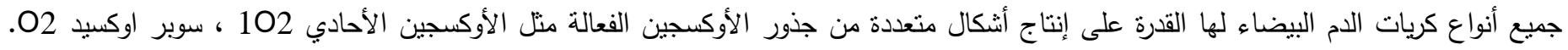

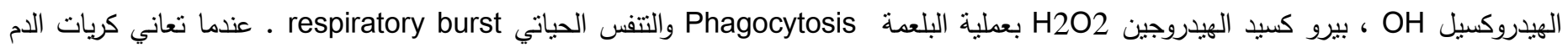

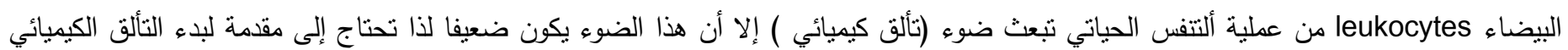

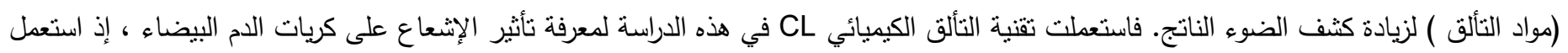


محلول اللومينول المuminol لزيادة كثف شدة الضوء • إنّ أشعة كاما سوف تولد الجذور الحرة من تفاعلات الإثارة للمركبات ـ إذ أن الضرر الجسمي الناتج من الإشعاع يمكن تحمله إذا كان تعرض الجسم الكلي لمستوى واطئ منه ممتد لفترة طويلة من الزمن ، إذ أن الحساسية والممانعة والقدرة التفاعلية لكريات الدم البيض تستجيب بصورة مختلفة لأشعة كاما تبعاً لخصائصها وميكانيكيات إصلاح الجسم • إذ تضمن البحث دراسة تأثير الجرع لأشعة كاما على الجى خلايا الدم لكل من عينات السيطرة والاختبار لنفس درجة الحموضة ـ فلاحظنا أن عدد خلايا الدم تقل مع زيادة الجرع ، إن تغير عدد كريات الدم البيض تؤدي إلى تغير قيمة التألق .

\section{Introduction}

In the last 15 years, the utility of luminescent labels has steadily increased. The phenomenon has been applied to biomedical science in immunoassays, DNA probe assays, and measurement of important enzymes .The term Chemiluminescence was first coined by Eilhardt Weideman in $1888^{[1]}$. The reactions Chemiluminescence occur oxidize organic compounds as the working principle of these compounds being transferred potential energy stored in chemical bonds for reactants into energy radiation in the visible portion of the electromagnetic spectrum. As the conversion of chemical energy into energy of radiation depends on the type of interactions and installed, these interactions occur oxidize organic compounds such as oxidation reactions Lophine, Lucigenin, Luminol \& Isoluminol[2] . It can be represented as:

$[\mathrm{A}]+[\mathrm{B}] \rightarrow[\diamond] \rightarrow[$ Products $]+$ light

where $[\diamond]$ is a highly energetic intermediate compound produced from a chemical activation reaction when two reagents $(\mathrm{A}$ and $\mathrm{B})$ are mixed .The $[\diamond]$ is short-lived and returns to a lower energy state by emitting visible light [3-4]. At present, diverse CL systems and the combination of CL and other detection methods appear in the literature [5]. Luminol is one of the earliest and most common CL reagents used in CL reaction [6]. Luminol-dependent Chemiluminescence(CL) assays provide an indirect but sensitive and rapid measurement of oxygen radical production by phagocytes although it should be noted that Phagocytosis per se is not required for this production[7]. Phagocytosis is one of the oxygen depending processes in organisms [8]. Therefore, the oxygen demand is strongly increased (respiratory burst) [9]. During this process, oxygen is converted into superoxide anions, hydrogen peroxide, monomolecular oxygen and hydroxyl radicals by means of several kinds of phagocytic cells (e.g. neutrophil, eosinophil and basophile leucocytes, macrophages) Because of the very weak native luminescence phenomena, Luminol or Lucigenin dependent Chemiluminescence have been used frequently for the detection of super oxide radical in biological systems
[10].These extra cellular highly reactive oxygen species (ROS) cause many biological effects such as destruction of bacterial cells, parasites and tumor cells, promoting inflammation and modulating the immune reaction [11].

\section{Methods}

\section{Blood samples}

Venous blood samples were obtained from apparently healthy volunteers aged 20-55 years using vials with heparin as the anticoagulant.

\section{Chemicals and reagents}

Tris- $\mathrm{HCl}$ stock solution was prepared using the following procedure: $12.1 \mathrm{~g}$ of Tris (Fluka-Garantte, Germany) was dissolved in $500 \mathrm{ml}$ distilled water , then $50 \mathrm{ml}$ of the Tris solution was added to $41.4 \mathrm{ml}$ of 0.2 $\mathrm{M} \mathrm{HCl}$ (Fluka-Garantte) and diluted to $200 \mathrm{ml}$ with distilled water. The final Tris- $\mathrm{HCl}$ solution morality was $0.015 \mathrm{M}$ at $\mathrm{pH} 7.4$.

CL inducer : In order to activate granulocytes to burst Luminol- dependent CL., a medium of $9.57 \mathrm{~g}$ $(165 \mathrm{M}) \mathrm{NaCl}$ (Riadel-dehaen) , $0.25 \mathrm{gm}(2.25 \mathrm{M})$ $\mathrm{CaCl} 2$ were added to $5.82 \mathrm{gm}(25 \mathrm{M}) \mathrm{BaSo} 4$ (RiadelDehaen) dissolved in $1000 \mathrm{ml}$ distilled water .

\section{Luminol solution}

This was made by dissolving $0.02 \mathrm{~g}$ Luminol (3amino-phthalhydrazide ) (Sigma Chemical Company ) in $2 \mathrm{ml}$ of $0.2 \mathrm{M} \mathrm{NaOH}$ (Riadel Dehaen), This stock solution was further diluted up to $100 \mathrm{ml}$ with deionized water (Basra Petrochemical Instillation ) and Kept prior to use .

\section{Procedure}

\section{Irradiation of the blood Samples}

Been used a radioactive effective source equipped by the company (J.I.Shepherdand Associates California, 
1978) Energy emitted by (662 Kev) As it has been exposing $2 \mathrm{~cm} 3$ from the blood to the gamma rays and the distance between the radiation source and the sample is $5 \mathrm{~cm}$ and a source of diameter user $(2.8 \mathrm{~cm})$. Put the radioactive source of in a vertical and Bottom. The blood sample either the radiation exposure was for different time periods as shown in photograph (1), which is composed of :
a) Water bath
b) Holder
c) A blood sample without irradiation
d) Thermometer
e) A blood sample under irradiation

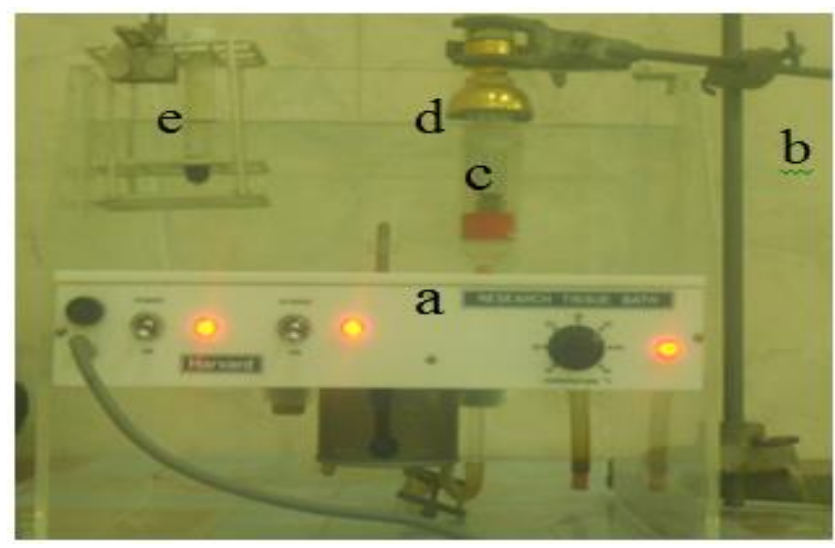

Photograph (1): Photo showing blood irradiation method.

\section{Chemiluminescence measurement}

Test and control samples were assayed for functional activity (free radical concentration released). The reaction mixture consisted of: $0.2 \mathrm{ml} \mathrm{CL}$ - inducer, $0.1 \mathrm{ml} \mathrm{NaOH}$ and $0.2 \mathrm{ml}$ Luminol in a $5 \mathrm{ml}$ beaker. Add to that mixture of $.02 \mathrm{ml}$ blood and placed in a photon counting system under room temperature during the counting. Chemiluminescence (CL) was continuously recorded on a chart recorder until it peaked and demonstrated a definite decline. The peak height (in $\mathrm{mm}$ ) of CL kinetic curves represents the granulocyte functional activity. The data were estimated in relative arbitrary units for comparison of the results as shown in Photograph (2). This device is designed in the Department of Physiology and Medical Physics I Basrah University College of Medicine which is composed of:

Photomultiplier tube (PMT)

PM. pre. Amp. Built in
Recorder chart

Reaction vessel with jacket

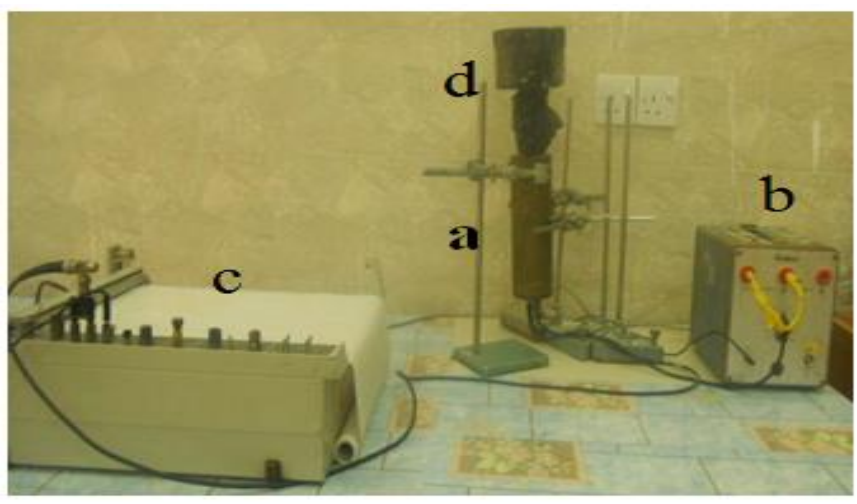

Photograph (2): Showing of Chemiluminescence apparatus used [12]

\section{Statistical analysis}

The results were analyzed using (SPSS) Statistical software probability value of $(<0.05)$ was considered to be statically significant. Results of granulocytes functional activity were expressed as (mean \pm SD), and a comparison between control $(\mathrm{C})$ and test $(\mathrm{t})$ Results were analyzed for significance using the t-test, with a Pvalue $<0.05$ indicating statistical significance.

\section{$\underline{\text { Results and discussion }}$}

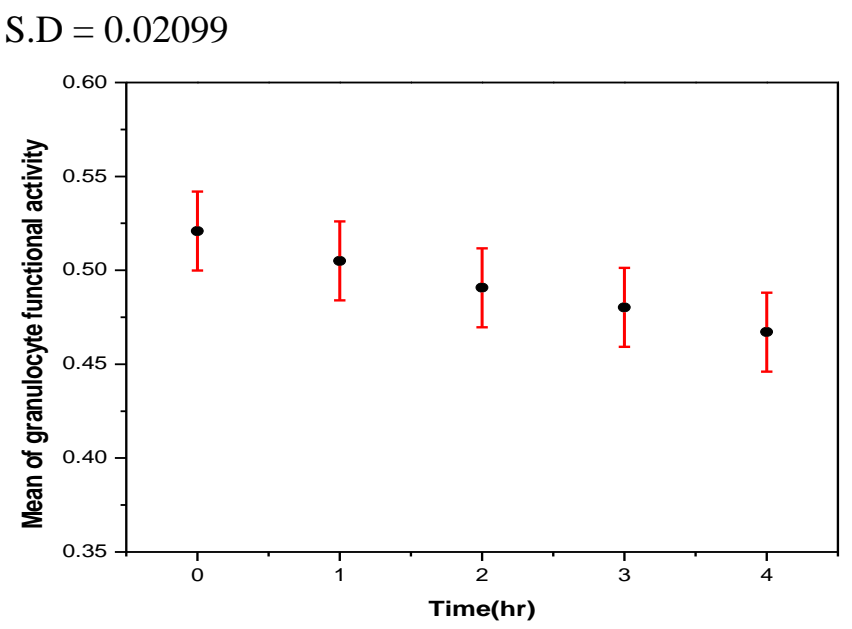

Figure.1a: Mean of Granulocyte function activity of white blood Cells to different time intervals of the five samples. 
S.D $=0.02465$

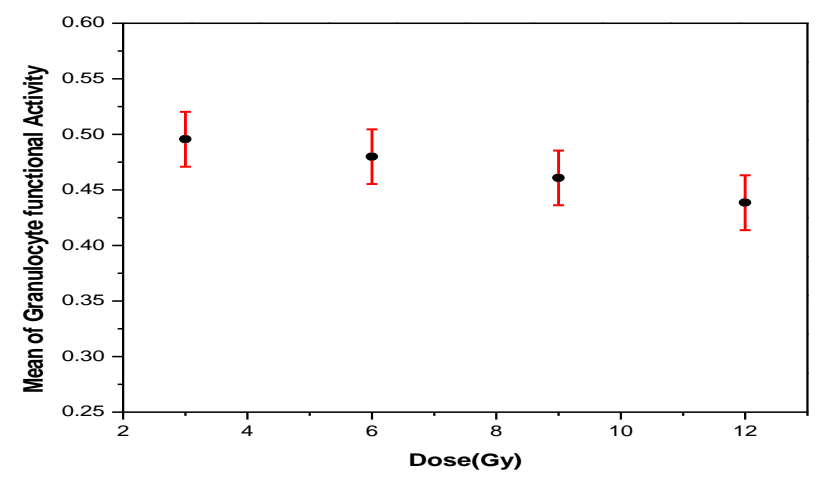

Figure.1b: Mean of Granulocyte function activity of white blood cells to different doses (Gray) of the five samples.

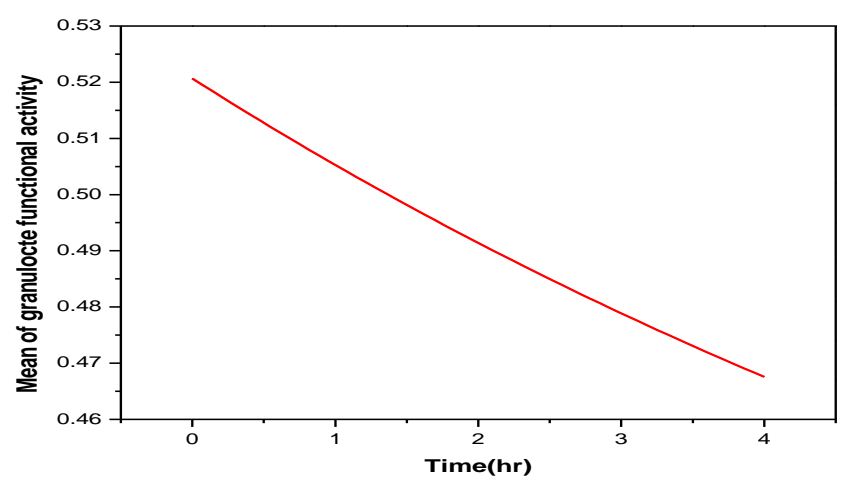

Figure.2a: Mean of G.F.A. as a function of Time (hour) for average samples.

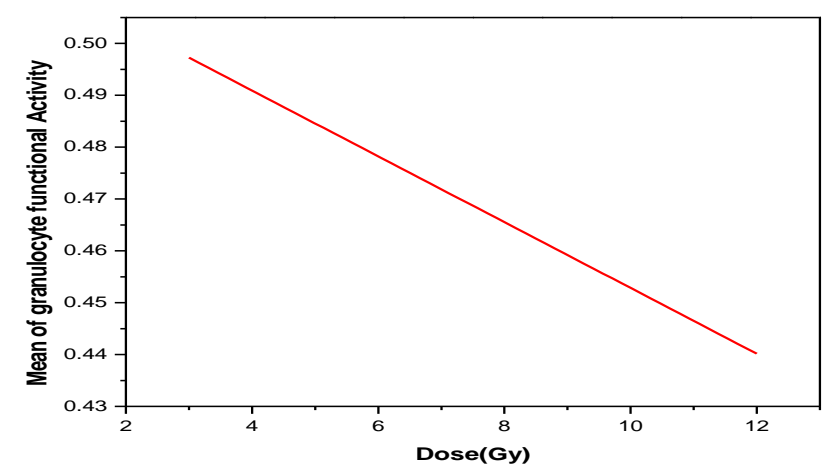

Figure.2b: Mean of G.F.A. as a function of dose (Gray) for average samples .

Activity inhibition $\%=\frac{t-c}{c} \times 100 \%{ }^{[13]}$

T: Test sample

C: Control sample
Tahle.1a:CI inhihition at different time interval

\begin{tabular}{|c|c|c|}
\hline $\begin{array}{c}\text { Time(hour) } \\
\text { inhibition }\end{array}$ & $\begin{array}{c}\text { Mean } \\
(\mathrm{CL})\end{array}$ & Activity inhibition\% \\
\hline 1 & 0.505 & 3.0524 \\
\hline 2 & 0.4907 & 5.7976 \\
\hline 3 & 0.4802 & 7.8133 \\
\hline 4 & 0.4670 & 10.3474 \\
\hline
\end{tabular}

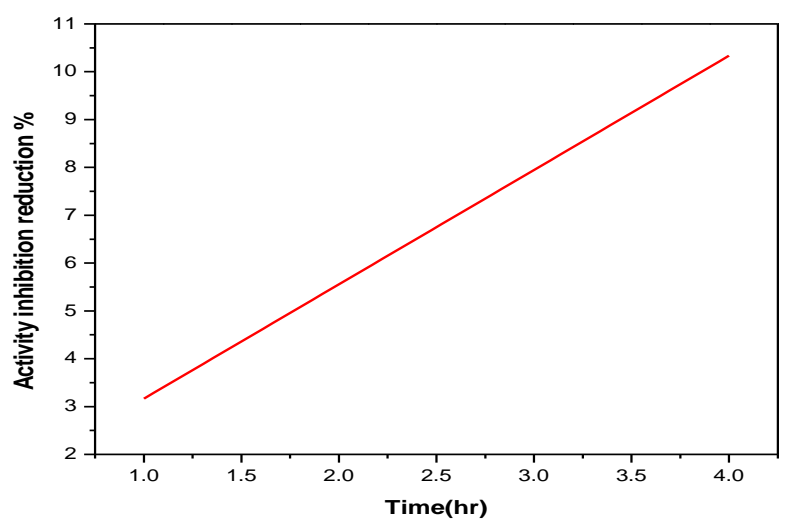

Figure.3a. Mean of the percentage of curved inhibition reduction to the average number of phagocytic white blood cells of the five samples for different time periods.

Table.1b: CL inhibition at different Doses.

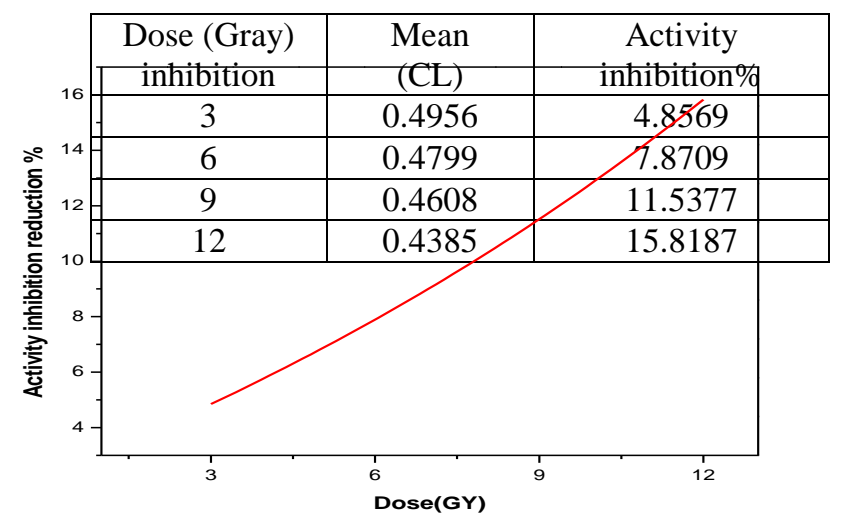

Figure.3b. Mean of the percentage of curved inhibition reduction to the average number of phagocytic white blood cells of the five samples

$\underline{\text { Dis }}$ of different doses.

The present study is preliminary to measure the granulocytes functional activity by mean of Chemiluminescence (CL) levels in blood samples before and after exposed to low level of gamma ray, 
This study revealed a significant decrease in CL functional activity values for the same number of cells and it's a dose dependents manner as shown from the functional activity of CL. Note the difference between test (Irradiated samples) and control (not irradiated samples) to study the effect of irradiation for different time periods and the decrease in granulocytes functional activity of white blood cells, as in the figure.1a, figure. $1 \mathrm{~b}$.The percentage reduction in $\mathrm{CL}$ functional activity is Shown in Figure.3a, figure.3b this attributed to the lethal or sub lethal damage of cell during irradiation. This study revealed a significant elevation of damage on increasing the dose of irradiation as low as in this level study. This implies that the granulocytes are so sensitive to low irradiation of gamma ray. This study shows that the granulocyte Functional Activity of white blood cells for samples five before irradiation due to time effect was higher than the effect of dose by $4.21 \%$ is shown in figure. $2 \mathrm{a} \&$ figure. $2 \mathrm{~b}$.

\section{Conclusions}

Granulocytes cells experiencing significantly the formation of free radicals indicated by continuing production of effective oxygen species upon exposure to a small dose of radiation.

\section{References}

Carlson R, Lewis SW, Lim KF, Seeing the light using Chemiluminescence to demonstrate chemical fundamentals. Aust J Chem Educ, 14: 51-53, (2000) .

Xiao Q, Li H, Lin JM, Development of a highly sensitive magnetic particle- based Chemiluminescence enzyme immunoassay for thyroid stimulating hormone and comparison with two other immunoassays. Clinical Chimica Acta ,411 : 1151-1153, (2010).

Ram S, Siar CH, Chemiluminescence as a diagnostic aid in the detection of oral cancer and potentially malignant epithelial lesions. Int J Oral Maxillofac Surg, 34: 521-527, (2005).

J.L.S. Araujo-Filho, M.R. M.J. and L.B. C. JR, "Potential Applications of the Chemiluminescent methods in Tumoral diseases Investigation " Vol 2/Issue 2/Apr-Jun 2011.

M. Yamaguchi, H. Yoshida, H. Nohta, J. Chromatogr. A 950 (2002).

Hao Chen, Feng Gao, Rong He, Daxiang Cui," Chemiluminescence of luminol catalyzed by silver nanoparticles ", Journal of Colloid and Interface Science $315: 158-163(2007)$.

I.P. Gormley, M.J. Kowolik and R.T. Cullent, "The chemiluminescent response of human phagocytic cells to mineral dusts "Br. exp. Path. (I985) 66, 409-4I6 .

Babior BM (1984) The respiratory burst of phagocytes. J Clin Invest. 73: 599-601.

Borg v. Zepelin M, Schuff-Werner Chemiluminescence of polymorpho nuclear granulocytes in the presence of selected candida species Mycoses 35:121-129(1992) .

Dahlgren C, Stendal Role of myeloperoxidase in luminol-dependent Chemiluminescence of polymorphonuclear leukocytes. Infect and Immun. 39: 736-741 (1983) .

Boveris A, Cadenas E, Chance B Ultraweak Chemiluminescence: a sensitive assay for oxidative radical reactions. Fed. 195-198 (1981).

G. S. AL-Thaher " A Study of The Activity of Human Granulocytes By Mean of Chemiluminescence " M.Sc.Thesis, Department of Biomedical Physics ,Univ.of Basrah, Iraq (1994) .

H., P.H. Principles of Hematology,WMC. Brown Publishers, 1997. 